\title{
POKOK NGUDUD KERETEK: KEBIASAAN NGUDUD DAN MUNCULNYA 'PABRIK KERETEK' DI KEDIRI, JAWA TIMUR, 1970-AN
}

\author{
POKOK NGUDUD KERETEK: \\ SMOKING AND THE EMERGENCE OF \\ 'PABRIK KERETEK' IN KEDIRI OF EAST JAVA, \\ $1970 S$ \\ Ronal Ridhoi dan Moh. Nazri Adlani \\ Jurusan Sejarah Fakultas Ilmu Sosial Universitas Negeri Malang, Indonesia \\ ronal.ridhoi.fis@um.ac.id, nazrigentholet@gmail.com
}

Diterima tanggal 6 Desember 2019

Disetujui tanggal 15 September 2020

\begin{abstract}
Smoking, cigarette, and keretek have already been addiction to Indonesian peoples, especially in Kediri. Since the 1950s, Kediri has been recognized by its largest cigarette factory, namely PT Gudang Garam. This study focuses on the linkages between ngudud (smoking) and 'pabrik keretek' (micro-scale cigarette factory), and why ngudud is still existed as a habit until nowadays. This research used historical method by perusing archives, online reports, articles, books, and interviews. This study indicates that ngudud was affected by Chinese immigrants who introduced keretek to Kediri since the second half of $20^{\text {th }}$ century, and it has a linkage to the emergence of 'pabrik keretek' on the next period. Ngudud, as a habit, is still existed because keretek became more popular in 1970s and it has been used for daily activities and religious rituals in Kediri.
\end{abstract}

Keywords: ngudud, 'pabrik keretek', Kediri, and East Java.

ABSTRAK
Merokok, rokok, dan keretek sudah menjadi candu bagi orang Indonesia, khususnya di
Kediri. Sejak tahun 1950-an, Kediri sudah dikenal banyak orang dengan pabrik rokok
terbesarnya, yaitu PT Gudang Garam. Studi ini memfokuskan pada keterkaitan ngudud
(merokok) dengan 'pabrik keretek' (pabrik rokok skala mikro), dan mengapa kebiasaan
ngudud tidak menghilang dalam perkembangan zaman. Penelitian ini menggunakan metode
sejarah dengan melakukan pembacaan secara mendalam sumber-sumber berupa arsip, berita
daring, artikel, buku, dan hasil wawancara. Studi ini menunjukan bahwa kebiasaan ngudud
dipengaruhi oleh pengenalan keretek oleh para imigran Tionghoa di Kediri sejak paruh
kedua abad ke-20, dan menunjukkan keterkaitan dengan munculnya 'pabrik keretek' pada

DOI: 10.33652/handep.v4.i1.90 
periode berikutnya. Kebiasaan ngudud yang tidak bisa hilang hingga saat ini disebabkan oleh populernya rokok keretek di tahun 1970-an dan penggunaan rokok keretek untuk aktivitas sehari-hari dan ritual keagamaan di Kediri.

Kata kunci: ngudud, 'pabrik keretek', Kediri, dan Jawa Timur.

\section{A. PENDAHULUAN}

"Saimun saying, 'Please, just one, Tam'. Itam looked at him and he handed his kretek to Saimun, they blew the smoke through their nostrils, slowly and for the moment they forgot the drizzling rain, the dirt and smell of the truck, ... the warmth of the cigarette upon the tongue and the relaxation of the body." (Lubis, 1963:16)

Percakapan di atas merupakan kutipan dari novel Twilight in Jakarta karya Mochtar Lubis tahun 1963. Di awal novel tersebut diceritakan dua orang pemulung bernama Saimun dan Itam yang sedang memulung sampah di sebuah TPA di Jakarta. Saimun yang kelaparan karena sejak pagi belum makan menghampiri temannya yang bernama Itam dan meminta sebatang rokok keretek. Setelah menghisapnya, mereka berdua menjadi rileks dan seakan lupa kalau pekerjaan sebagai pemulung itu berada di tempat kotor dan bau.

Salah satu fenomena menarik yang dapat dilihat dari novel tersebut yaitu tentang rokok keretek. Di mana rokok keretek seringkali diidentikkan dengan golongan miskin, dan rokok putih (white foreign cigarette) seringkali diidentikkan dengan politisi dan golongan menengah ke atas. Padahal sejak pertengahan abad ke-19 rokok keretek sangat terkenal di kalangan bangsawan dan politisi (Arnez 2009:64). Rokok keretek juga menjadi simbol nasionalisme ekonomi rakyat Indonesia. Industri keretek pascakemerdekaan juga memberikan keuntungan bagi negara dan kesejahteraan pada masyarakat Indonesia (Margana et al. 2014:17374).

Tulisan ini berusaha untuk menelaah bagaimana kebiasaan ngudud masyarakat di Kediri dan keterkaitannya dengan pabrik keretek yang muncul di tahun 1970-an. Selain itu, tulisan ini juga ingin menjawab mengapa kebiasaan ngudud keretek bagi sebagian besar masyarakat Kediri tidak menghilang dalam perkembangan zaman.

Tulisan ini memfokuskan pada wilayah Kabupaten Kediri. Daerah ini dipilih sebagai spasial penelitian karena mempunyai banyak pabrik keretek. Tercatat ada ratusan pabrik keretek di Kabupaten Kediri hingga 2008 dan di Kota Kediri hanya ada enam pabrik (Topatimasang 2010:90). Selain itu, masyarakatnya merupakan penggemar rokok keretek dan mayoritas bekerja sebagai pengusaha dan buruh pabrik keretek. Hal menarik lainnya yaitu produksi rokok di pabrik keretek yang ada di daerah tersebut juga dipasarkan di luar Kediri, seperti Pabrik Kretek Kanigoro yang memasarkan rokoknya 
ke Trenggalek, Tulungagung, Blitar, dan Nganjuk, bahkan juga ke luar Jawa, yaitu Kalimantan (Estik 2018; Hartati 2018).

Konsep 'pabrik keretek' dalam tulisan adalah industri skala kecil (home industry). Masyarakat Kediri terbiasa menyebut industri kecil penghasil rokok keretek dengan sebutan 'pabrik keretek'. Mereka memproduksi rokok dengan Sistem Kerja Tangan (SKT). Sementara untuk industri rokok berskala besar, masyarakat menyebutnya dengan 'Gudang Garam'. Penyebutan tersebut disebabkan Pabrik Rokok Gudang Garam adalah perusahaan rokok terbesar di Kediri yang memproduksi rokok dengan Sistem Kerja Mesin (SKM), meskipun pada awal berdiri perusahaan ini menggunakan SKT.

Kebiasaan merokok bagi sebagian besar masyarakat Kediri telah menjadikan mereka kecanduan menghisap rokok. Dalam hal ini, rokok keretek telah menjadi kebutuhan bagi sebagian besar masyarakat Kediri terutama laki-laki yang sudah bekerja. Sebagai dampaknya, untuk memenuhi kebutuhan tersebut, pasaran rokok keretek meluas di Kediri hingga daerahdaerah di sekitarnya seperti Blitar dan Tulungagung.

Industri keretek yang tersebar di Kediri dan sekitarnya kebanyakan berskala kecil. Namun, produk yang dihasilkan tetap bisa bersaing dan dapat menciptakan peluang kerja bagi penduduk setempat. Selain itu juga mampu meningkatkan pendapatan di tingkat lokal dan daerah, mengangkat sumber daya lokal, serta dapat memberi kontribusi terhadap pemerintah. Pada dasarnya industri keretek rumahan tersebut sudah mempunyai pasar lokal dan regional. Seperti diungkapkan Masyhari (2019), rokok keretek dari industri rumahan mampu menyumbangkan devisa yang cukup besar untuk daerah Kediri dengan Produk Domestik Regional Bruto (PDRB) Kediri atas dasar harga berlaku mencapai sekitar 116,06 triliun pada 2017 dan terus bertambah hingga sekarang. Selain terkenal dengan sebutan Kota Tahu, munculnya industri-industri keretek dan berkat kemampuan meracik bahan rokok keretek, membuat Kediri tersohor sebagai salah satu daerah sentra produksi keretek di Indonesia.

Kajian mengenai perkembangan industri keretek di Indonesia sudah banyak dibahas oleh para peneliti lokal maupun asing. Margana et al. dalam Kretek Indonesia: Dari Nasionalisme hingga Warisan Budaya (2014) membahas industri rokok yang muncul di Indonesia sejak abad ke-20 merupakan respons kolektif dari masyarakat tingkat lokal Indonesia untuk melepaskan diri dari kolonialisme bangsa Barat. Dari situ kemudian muncul ekonomi nasionalis yang bersumber dari industri rokok keretek. Oleh sebab itu, rokok keretek merupakan warisan budaya yang harus dilestarikan hingga saat ini.

Kajian lainnya yaitu artikel dari Lepi T. Tarmidi berjudul Changing Structure and Competition in the Kretek 
Cigarette Industry (1996) juga menelaah rokok keretek Indonesia yang awalnya diproduksi oleh industri kecil hingga diproduksi oleh industri manufaktur skala besar. Keretek merupakan penyumbang devisa bagi Indonesia, juga menyerap banyak sekali tenaga kerja. Namun seiring perkembangan zaman, produksi rokok keretek skala kecil tidak dapat bersaing dengan pabrik besar karena monopoli perdagangan dan masuknya industri rokok luar negeri di Indonesia sejak periode sejak Orde Baru. Kajian tersebut relevan dengan tema tulisan ini karena sejak 1990-an pabrik rokok di Kediri mengalami pasang surut produksi.

Selanjutnya yaitu tulisan Monica Arnez, Tobacco and Kretek: Indonesian Drugs in Historical Change (2009) yang menunjukkan perkembangan industri keretek di Indonesia sejak awal abad ke-20. Selain itu, Arnez juga membahas intervensi yang dilakukan oleh pemerintah dan pengusaha asing yang masuk ke Indonesia hingga mempengaruhi produksi rokok keretek. Di akhir juga dipaparkan bagaimana pandangan masyarakat terhadap keretek dan kebiasaan merokok di Indonesia.

Selain itu, Imaniar Purbasari, menulis Perkembangan Industri Rokok Kretek Kudus 1908-1964 (2010). Hasil penelitiannya memaparkan bahwa munculnya industri rokok di Kudus lebih besar berdampak positif diantaranya memajukan perekonomian dan memberikan pengaruh besar terhadap perubahan sosial masyarakat lokal yang lebih sejahtera dibanding daerah lain di Kudus.

Menurut Topatimasang (2010), industri keretek membuktikan bahwa sentra ekonomi ini menjadi satusatunya industri yang mampu bertahan dari berbagai dinamika sosial dan politik, perang dan pemberontakan bersenjata, serta krisis perekonomian lokal, nasional maupun global. Hal inilah yang membuat sejarah perindustrian keretek khususnya di Kediri unik dan menarik untuk dipelajari.

Beberapa tulisan di atas merupakan kajian makro dari sejarah industri keretek. Selain itu juga masih sedikit disinggung tentang kebiasaan merokok atau ngudud di Indonesia. Oleh sebab itu, dalam tulisan ini penulis lebih memfokuskan kajian pada kebiasaan ngudud dan perkembangan industri keretek skala mikro, serta pengaruhnya terhadap perekonomian masyarakat masa Orde Baru. Selain itu juga dibahas keterkaitan pabrik keretek dengan kebiasaan ngudud masyarakat Kediri yang tidak bisa hilang hingga saat ini.

\section{B. METODE}

Penelitian ini menggunakan metode sejarah yang terdiri atas empat tahap, yaitu heuristik, kritik, interpretasi, dan historiografi. Dengan melakukan pembacaan secara mendalam terhadap beberapa sumber seperti arsip, berita daring, buku, artikel, dan wawancara mendalam terhadap narasumber yang relevan, penelitian ini berusaha 
menelaah sejarah industri keretek skala kecil (industri rumahan) di Kabupaten Kediri.

Peneliti menggunakan sumbersumber berupa arsip Panca Warsa Kediri 1977-1982, wawancara dengan Estik (Pemimpin Pabrik Kretek Gudang Rasa), wawancara dengan Mawardi (Pemilik Pabrik Kretek Kanigoro/KN), dan wawancara dengan Hartati (bendahara Pabrik Kretek Kanigoro/ $\mathrm{KN}$ ). Selain itu, penulis juga menggunakan literatur pendukung yaitu buku Membunuh Indonesia: Konspirasi Global Penghancuran Kretek dan artiker jurnal "Analisis SektorSektor Ekonomi dalam Rangka Pengembangan Kebijakan Ekonomi Kediri" serta sumber-sumber lainnya. Beberapa sumber tersebut yang mendukung peneliti ketika merangkai fakta-fakta sejarah tentang industri keretek rumahan dan budaya $n g u d u d$ di Kediri menjadi sebuah historiografi.

\section{HASIL DAN BAHASAN}

\section{Cengkih dan Tembakau: Menanam} atau Membeli Bahan Baku?

Komoditas cengkih pernah menjadi salah satu penggerak roda perekonomian masyarakat. Bahkan sebelum pembentukan Badan Penyangga dan Pemasaran Cengkeh (BPPC), komoditas ini meningkat setiap tahunnya. Pada dasawarsa 1970an cengkeh menjadi penyumbang terbesar keuangan negara (EA 2013:4). Petani cengkih menyiasati masa tanam hingga berbunga sebagai tabungan penghasilan seperti untuk perihal pendidikan. Saat seorang anak lahir mereka menanam pohon cengkih. Dalam waktu lima hingga tujuh tahun, saat anak-anak mereka mulai bersekolah, pohon cengkih telah menghasilkan. Komoditas cengkih mempunyai peran menyokong sekitar lima juta petani dan tenaga kerja pertanian cengkih di Indonesia (Wibisono 2014).

Cengkih merupakan tanaman yang punya nilai sejarah dan ekonomi yang sangat tinggi. Tanaman ini hanya bisa tumbuh serta berkembang baik di Indonesia. Rempah berbentuk seperti kuku ini telah dikenal luas sejak ribuan tahun lalu. Orang Cina mengenal sebagai rempah kuku, orang Barat menyebutnya dengan cloves karena merujuk bentuk cengkih yang menyerupai cakar (Wibisono 2014).

Di Kediri pada masa Orde Baru, terdapat lima perusahaan perkebunan besar yang pada umumnya terletak di daerah pegunungan (Gunung Kelud dan Gunung Wilis). Luas perkebunan besar seluruhnya ada 5.125 ha, baik yang diusahakan PT Perkebunan XXIII (PTP XXIII) maupun pengusaha swasta nasional dan daerah. Adapun jenis komoditas perkebunan yang diusahakan salah satunya adalah cengkih. Tanaman cengkih mulai digalakkan untuk perkebunan pada 1974 sebagai usaha diversifikasi. Kelima perkebunan besar yang ada di daerah Kediri mempunyai latar belakang pengelolaan yang berbeda, walaupun dulunya sama-sama milik pengusaha Belanda. Khususnya untuk 
Handep Jurnal Sejarah dan Budaya Vol. 4, No. 1, Desember 2020, hlm. 1-18

perkebunan yang dikelola PTP XXIII adalah perkebunan besar yang masih cukup baik. Ditinjau dari segi pengelolaannya, kelima perkebunan besar di Kediri yang dikelola PTP XIII sebanyak satu perkebunan, perusahaan daerah satu perkebunan, dan pengusaha swasta nasional sebanyak tiga perkebunan.

Sementara itu, komoditas cengkih yang diusahakan oleh pengelola perkebunan dapat dilihat pada tabel berikut:

\begin{tabular}{lll}
\hline Perkebunan & Pengelola & Jumlah \\
\hline Cengkih & PTP XXIII & $\begin{array}{l}62,99 \text { ha } \\
(25 \%)\end{array}$ \\
\hline & Perusahaan & $\begin{array}{l}188,91 \mathrm{ha} \\
(75 \%)\end{array}$ \\
\hline Daerah & $\begin{array}{l}251,90 \mathrm{ha} \\
(100 \%)\end{array}$
\end{tabular}

Tabel 1. Jumlah Luas Lahan Perkebunan Cengkih di Kediri. Sumber: Peringatan Panca Warsa 1977-1982 DPRD Tingkat II 1983.

Ditinjau dari segi kepentingan nasional, maka eksistensi perkebunan cengkih sangat berperan dalam memproduksi bahan-bahan ekspor, maupun barang konsumsi dalam negeri (cengkih) yang kesemuanya memiliki kontribusi dalam menyumbang devisa negara. Pada 1980, pemerintahan pusat menargetkan devisa sebesar \$5,5 milyar pada akhir Pelita VI.

Selain itu, kegiatan peremajaan atau perluasan tanaman merupakan suatu usaha untuk pengembangan produksi. Hal ini dapat dilihat dari luas pembibitan tanaman di perkebunan besar yang mencapai luas 23,44 ha sebagai berikut:

\begin{tabular}{lc}
\hline \multicolumn{1}{c}{ Pembibitan } & Luas lahan \\
\hline Kopi & 12,62 ha \\
\hline Karet & 9,32 ha \\
\hline Cokelat & 0,50 ha \\
\hline Cengkih & $3, \ldots$ ha \\
\hline
\end{tabular}

Tabel 2. Luas Lahan Pembibitan Tanaman. Sumber: Peringatan Panca Warsa 1977-1982 DPRD Tingkat II 1983.

Dari luas pembibitan tersebut akan bisa ditanam bibit sebanyak 1.172 .000 batang tanaman. Penanaman baru di daerah Kediri yang menunjukan kemajuan yang pesat adalah tanaman cengkih, cokelat, dan kopi. Untuk gambaran luas perkebunan tersebut pada 1977 dibandingkan dengan pada 1982 sekarang ini adalah sebagai berikut:

\begin{tabular}{lccc}
\hline Komoditas & \multicolumn{2}{c}{ Luas lahan } & Kenaikan \\
\cline { 2 - 3 } & 1977 & 1982 & \\
\hline Cengkih & $\begin{array}{r}122,6 \\
5 \text { ha }\end{array}$ & $\begin{array}{c}251,9 \\
0 \text { ha }\end{array}$ & $105,3 \%$ \\
& & & \\
\hline Cokelat & 820,4 & 950,2 & \multirow{2}{*}{$15,9 \%$} \\
& 8 ha & 8 ha & \\
\hline Kopi & 2.119 & 2.588, & $22,1 \%$ \\
&, 44 ha & 36 ha & \\
& & & \\
\hline
\end{tabular}

Tabel 3. Perbandingan Luas Lahan Perkebunan. Sumber: Peringatan Panca Warsa 1977-1982 DPRD Tingkat II 1983.

Dari Tabel 3 diketahui bahwa peningkatan penanaman komoditas cengkih di Kediri jauh lebih signifikan dibandingkan komoditas lainnya. Ini merupakan dampak dari dua fenomena 
besar. Pertama, sejak tahun 1970-an mulai booming kembali di kalangan para pecandu rokok. Sehingga, banyak pabrik keretek yang bermunculan di Kediri yang secara langsung berdampak pada peningkatan kebutuhan akan cengkih. Kedua, PT Gudang Garam mulai melakukan mekanisasi terhadap perusahaannya dengan memproduksi rokok menggunakan mesin (Arnez 2009:56; Tarmidi 1996). Hal ini menjadikan produksi rokok semakin cepat dan banyak, serta membutuhkan cengkih yang banyak pula.

Demikian juga dengan makin meluasnya tanaman muda yang produktif serta usaha-usaha intensifikasi, maka untuk ketiga komoditas tersebut mengalami kenaikan produksi. Tabel berikut ini merupakan kenaikan produksi tiga komoditas perkebunan di Kediri:

\begin{tabular}{lccc}
\hline Komoditas & \multicolumn{2}{c}{ Produksi (kg) } & $\begin{array}{c}\text { Kenai } \\
\text { kan }\end{array}$ \\
\cline { 2 - 3 } & 1977 & 1981 & \\
\hline Cengkih & 3.320 & $\begin{array}{c}12.16 \\
5\end{array}$ & $\begin{array}{c}266,4 \\
\%\end{array}$ \\
\hline Cokelat & 192.1 & 787.5 & 309,9 \\
& 25 & 44 & $\%$ \\
\hline Kopi & 1.574 & 1.769. & $12,4 \%$ \\
& .265 & 574 & \\
\hline
\end{tabular}

Tabel 4. Jumlah Kenaikan Produksi. Sumber: Peringatan Panca Warsa 1977-1982 DPRD Tingkat II 1983.

Tidak hanya perkebunan cengkih, perkebunan tembakau juga menjadi komoditas tanam utama di Kediri. Bahkan sejak periode kolonial daerah ini sudah dijadikan pemerintah sebagai area tanam tembakau. Liberalisasi ekonomi pada 1870 mengakibatkan semakin masifnya penanaman tembakau, baik oleh pemerintah kolonial maupun investor-investor. Margana et al. menjelaskan bahwa budidaya tembakau di perkebunan milik pemerintah kolonial di daerah Semarang, Banyumas, Kedu, Rembang, Besuki, Probolinggo, dan Kediri. Sementara untuk perkebunan milik swasta berada di Deli, Sumatra (Margana et al. 2014:219).

Oleh karena besarnya permintaan komoditas ini di pasar dunia dengan harga yang mahal, pakar sejarah lingkungan Indonesia Nawiyanto menyebut tembakau dengan istilah golden leaf atau green gold (daun emas/ emas hijau). Hal itu dikarenakan tembakau merupakan lahan bisnis yang menguntungkan, dapat meningkatkan perekonomian negara dan masyarakat, dan menyerap banyak tenaga kerja (Nawiyanto 2013:110). Hal ini menjadi keuntungan tersendiri bagi para petani tembakau dan para pengusaha yang berhubungan dengan tembakau, seperti industri rokok.

Tembakau yang digunakan oleh masyarakat Kediri untuk ngudud memang sengaja didatangkan dari berbagai daerah, utamanya dari wilayah Jember, Bondowoso, dan Kedu (khususnya Temanggung). Tembakau Kedu terkenal sejak lama karena kualitasnya yang bagus dan merupakan tembakau paling bagus di Pulau Jawa (Budiman dan Onghokham 2016:89). 
Handep Jurnal Sejarah dan Budaya Vol. 4, No. 1, Desember 2020, hlm. 1-18

Tembakau Temanggung yang terkenal tersebut memang pasar utamanya ke daerah Kudus, Malang, dan Kediri. Hingga pada awal 2000 pengusaha rokok keretek di Kediri masih mendatangkan tembakau dari daerah tersebut (Topatimasang 2010:29). Hal ini memang wajar karena tembakau Temanggung dinilai memiliki cita rasa yang khas untuk bahan baku pembuatan rokok keretek.

Lalu bagaimana dengan tembakau di Kediri itu sendiri? Mengapa hingga saat ini masih membeli dari Temanggung? Data tentang perkebunan tembakau di Kediri, khususnya pada 1970-an masih jarang ditemukan. Penulis mendapatkan sedikit data terkait sebaran perkebunan tembakau di Kediri yang dapat dilihat pada Tabel 5 berikut ini.

\begin{tabular}{clc}
\hline No. & Kecamatan & $\begin{array}{c}\text { Luas } \\
\text { Perkebunan } \\
\text { (ha) }\end{array}$ \\
\hline 1. & Banyakan & 69,9 \\
\hline 2. & Mojo & 20,07 \\
\hline 3. & Semen & 11,42 \\
\hline 4. & Tarokan & 13,26 \\
\hline 5. & Grogol & 43,11 \\
\hline 6. & Kandangan & 52,79 \\
\hline 7. & Kepung & 8,9 \\
\hline 8. & Badas & 14,55 \\
\hline Jumlah luas lahan & 234 ha
\end{tabular}

Tabel 5. Kecamatan Penghasil Tembakau di Kabupaten Kediri 1977. Sumber: diadaptasi dari Peringatan Panca Warsa 1977-1982 DPRD Tingkat II 1983.

Beberapa kecamatan yang perkebunan tembakaunya cukup luas mayoritas berada di lereng atau kaki gunung. Seperti Kecamatan Kandangan
(52,79 ha) yang lokasi perkebunannya di lereng Pegunungan Anjasmoro. Selain itu ada Kecamatan Banyakan (69,9 ha), Mojo (20,07 ha), dan Grogol (43,11 ha) yang lokasi perkebunannya di lereng Gunung Wilis. Selain itu juga ada Kecamatan Kepung (8,9 ha) yang lokasi perkebunannya di lereng Gunung Kelud. Daerah Kepung lebih sedikit perkebunan tembakaunya dibanding kecamatan lainnya. Hal ini disebabkan oleh intensifikasi penanaman cengkih, kopi, dan cokelat di lereng Gunung Kelud pada masa Orde Baru.

Belum ditemukan data tentang berapa banyak hasil perkebunan tembakau di Kediri yang tersebar di beberapa kecamatan tersebut. Namun tembakau lokal menjadi bahan baku utama produksi keretek di Kediri (Mawardi 2018; Estik 2018). Menurut penuturan sebagian besar penikmat keretek di Kediri, tembakau lokal memiliki cita rasa yang lebih halus daripada tembakau Temanggung. Meski demikian, pada periode 1970-an tembakau Temanggung tetap dipakai sebagai campuran rokok keretek di beberapa pabrik keretek Kediri. Rasa tembakau yang cukup kuat namun halus di tenggorokan membuat tembakau Temanggung tersebut mengungguli pamor tembakau lokal Kediri dan sekitarnya.

Catatan Haji Iskandar, seorang Manajer Pembelian Tembakau PT Djarum, menunjukkan fenomena yang menarik. Menurutnya, pasar rokok era 1970-an mayoritas adalah rokok keretek. Jenis rokok ini membutuhkan tembakau yang memiliki kandungan 
nikotin tinggi. Tembakau yang cocok dengan jenis rokok tersebut adalah tembakau Temanggung. Jadi sebagian besar produsen rokok keretek jika ingin produknya berkualitas maka yang dipakai adalah tembakau Temanggung. Iskandar yang bekerja di PT Djarum mencoba membuka lahan penanaman tembakau di lereng Gunung Arjuno dan Gunung Panderman (sekitar dua jam dari Kediri) sejak 1978-1984. Namun misinya tidak berhasil karena kualitas tembakau masih kalah dengan Temanggung (Wibisono 2013:18-19).

Berdasarkan catatan tersebut, maka sangat dimungkinkan kalau memang sebagian besar pengusaha rokok keretek di Kediri masih bergantung pada Temanggung, meskipun di Kediri dan daerah lain di Jawa Timur juga mengembangkan perkebunan tembakau. Hal ini penting karena mempengaruhi rasa dan produksi keretek di Kediri pada 1970-an.

\section{Kebiasaan Ngudud Masyarakat Kediri}

Keretek tidak bisa dilepaskan dalam ingatan dan keseharian masyarakat Kediri. Ketika warga mengadakan forum atau acara tertentu, rokok keretek yang diletakkan dalam gelas-gelas belimbing merupakan pemandangan yang umum dan tidak asing. Saat ada acara informal, rokok keretek sudah menjadi bagian dari sosialisasi antarwarga, dan sering dihadiahkan untuk menghormati dan menghargai seseorang karena bantuannya dalam hal tertentu. Hampir semua warung skala besar maupun skala kecil menjual rokok keretek, yang disandingkan dengan gula, beras, minyak kelapa, dan berbagai kebutuhan pokok lainnya. Sebagai produk kebudayaan, keretek juga dianggap sebagai penanda identitas (DM et al. 2012:28). Sejarah pernah mencatat bahwasannya keretek merupakan salah satu simbol bagi pergerakan nasional, yaitu ketika mahasiswa-mahasiswa Indonesia yang bangga merokok keretek ketika menimba ilmu di Belanda. Keretek juga merupakan simbol ekonomi nasionalis yang berusaha merespons dominasi ekonomi pemerintah kolonial yang mulai terpuruk pada saat Depresi Ekonomi 1930 (Margana et al. 2014).

Hampir mirip dengan pendapat Nawiyanto (2013:115) dan Basuki (2010) yang menyatakan bahwa kebiasaan merokok dapat membentuk identitas di kalangan masyarakat. Di Kediri bagian selatan, budaya ngudud juga menunjukkan pembentukan identitas tersebut. Mereka menggunakan rokok keretek sebagai pendamping kearifan lokal mereka. Seperti pada saat ritual sebelum menanam padi, bersih desa, kenduri budaya, pertunjukan jaranan dan acaraacara sakral lainnya. Oleh sebab itu, seringkali para pemuda saat ini menghubungkan rokok keretek dengan klenik, orang tua, hal-hal yang bernuansa mitos, dan sebagai penanda status sosial menengah ke bawah. Padahal kebudayaan merokok di daerah tersebut memang diawali oleh rokok keretek. Dari situ kemudian rokok 
Handep Jurnal Sejarah dan Budaya Vol. 4, No. 1, Desember 2020, hlm. 1-18

keretek menjadi identitas golongan tua dan golongan yang pada dasarnya mempunyai kondisi perekonomian menengah ke bawah. Adapun untuk golongan masyarakat menengah ke atas mayoritas menyukai rokok putih.

Masyarakat Kediri seringkali mengartikan keretek sebagai rokok yang tidak menggunakan filter (busa). Pada periode 1970-1990-an, rokok keretek bahkan identik dengan rokok yang dikonsumsi kalangan bawah. Padahal, jika ditinjau dari asal katanya, yang membedakan keretek dengan jenis rokok lain adalah kandungan cengkeh dan unsur rempah-rempah alami di dalamnya. Rokok putih (filter) hanya mengandung tembakau dan saus, sementara keretek adalah produk hasil racikan tembakau dan cacahan cengkeh, serta ada tambahan sedikit saus. Racikan khas lokal inilah yang membuat rokok keretek memiliki rasa dan aroma khas yang berbeda dari jenis rokok lainnya.

Kebiasaan merokok oleh masyarakat Nusantara sudah ada sejak diperkenalkannya tembakau pertama kali di Pulau Jawa oleh bangsa Portugis. Mereka membawa tanaman tembakau ke Pulau Jawa sekitar tahun 1600-an, sedangkan menurut penuturan Scott, seorang kepala tempat permukiman orang Inggris di Banten, pada sekitar awal abad ke-17 mengisap tembakau atau merokok telah dilakukan banyak orang di Pulau Jawa. Berdasarkan kedua catatan tersebut, dapat dikatakan bahwa tembakau dan pemakaiannya sebagai rokok telah ada di Jawa sejak awal abad ke-17 (Budiman 1987). Selain itu, keretek pada paruh kedua abad ke-19 juga berfungsi sebagai media penyembuhan. Rokok keretek terbukti dapat menyembuhkan penyakit asma (Arnez 2009:52; Nawiyanto 2013:112).

Kebiasaan merokok semakin berkembang di Jawa karena muncul rumor bahwa kebiasaan merokok dapat menyembuhkan sakit pernafasan (sesak nafas). Hal ini bermula dari Haji Djamari seseorang dari Kudus yang menderita sesak nafas di dadanya. Ia memelopori penggunaan minyak cengkeh untuk mengobati penyakitnya dan ternyata penyakitnya tersebut berangsur-angsur sembuh. Oleh karena Haji Djamari mempunyai naluri bisnis, ia mulai membuat rokok obat yang diproduksi skala kecil (industri rumahan). Rokoknya tersebut laku keras di pasaran. Saat itu rokok obat lebih dikenal dengan sebutan rokok cengkih, kemudian sebutannya berganti menjadi rokok keretek karena rokok ini jika dibakar berbunyi 'kretek-kretek' (Arnez 2009; Budiman 1987; Margana et al. 2014; Nawiyanto 2013; Tarmidi 1996).

Sejak awal abad ke-20 keretek telah menggantikan kebiasaan masyarakat Nusantara periode sebelumnya yang biasa mengunyah sirih (dalam bahasa Jawa nginang) (Margana et al. 2014:212). Pada tahun 1950 hingga awal 1960-an keretek menjadi kebiasaan dan candu di kalangan masyarakat Indonesia, baik untuk golongan menengah ke bawah 
maupun golongan menengah ke atas. Saat itu orang kaya memilih untuk merokok rokok putih produksi luar negeri hanya untuk prestise saja. Menurut mereka rokok keretek jelas lebih nikmat dan "smoking kretek means to enhance the awareness of life" (Arnez, 2009:63-64).

Di Kediri, pengaruh keretek baru muncul sejak awal abad ke-20. Hal itu tidak bisa dilepaskan dari pengaruh industri rokok Kudus. Kerusuhan rasial yang terjadi pada 1918 di Kudus menyebabkan banyak orang Tionghoa Kudus yang pindah ke Jawa Timur. Mereka membawa modal dan pengetahuannya tentang keretek dari daerah asal. Oleh sebab itu tidak mengherankan jika tiga daerah di Keresidenan Kediri (Blitar, Kediri, dan Tulungagung) mulai mengembangkan industri kretek (Margana et al. 2014:118).

Dari pengenalan keretek oleh orang Tionghoa Kudus tersebut kemudian muncul beberapa industri keretek, seperti "NV 93" dan "Inghwie" pada 1940 hingga 1950-an. Industri rokok tersebut pada akhirnya bisa menyejahterakan masyarakat karena banyak menyerap tenaga kerja (Tarmidi 1996). Kebiasaan ngudud masyarakat Kediri menjadi sebuah hal yang wajar mengingat ada beberapa industri rokok skala makro dan pabrik keretek (skala mikro) yang kemudian berkembang pada periode-periode berikutnya.

Satu hal menarik yang ditemukan di Kediri adalah ngudud bukan hanya kesenangan pribadi, tapi juga menjadi hidangan utama yang disajikan kepada tamu. Selain sebagai barang dagangan dan untuk komsumsi masyarakat, rokok juga terdapat dalam kepercayaan tradisional di masyarakat Kediri. Rokok sering dipakai sebagai salah satu sesaji (barang persembahan) yang disandingkan dengan bunga mawar, cempaka, kenanga, soka, dan melati. Sesaji ini dipersembahkan untuk berbagai macam kepentingan sehingga masyarakat menaruh sesaji di berbagai tempat, seperti di makam yang dikeramatkan, di persimpangan jalan, di dekat sumur, di jembatan, tepian sungai, bahkan di sawah sewaktu batang-batang padi mulai tumbuh. Selain itu, keretek juga tidak pernah absen dari kegiatan spiritual keagamaan seperti hidangan saat pengajian dan selamatan orang meninggal (ikhlasan).

Dari situ kemudian dapat disimpulkan bahwa kebiasaan ngudud masyarakat Kediri memang sudah ada sejak pengenalan kretek pada 1920-an. Kebiasaan tersebut memang mempunyai keterkaitan dengan munculnya pabrik keretek mengingat banyaknya pabrik skala kecil yang berkembang di daerah ini pada dekade berikutnya.

\section{Industri Keretek Skala Kecil di Kediri}

Istilah industri dapat diartikan sebagai perusahaan yang menjalankan kegiatan ekonomi dan tergolong dalam sektor sekunder. Industri juga diartikan sebagai kumpulan perusahaan penghasil barang yang sama dan terdapat dalam suatu pasar. Perusahaan 
Handep Jurnal Sejarah dan Budaya Vol. 4, No. 1, Desember 2020, hlm. 1-18

merupakan badan usaha yang menggunakan berbagai faktor produksi untuk menghasilkan barang-barang kebutuhan masyarakat. Hal itu merupakan kegiatan ekonomi yang mengolah bahan mentah menjadi barang setengah jadi atau jadi, yang dapat meningkatkan nilai tambah barang tersebut (Sukirno 2010:194).

Istilah industri sangat luas dan dapat dikaitkan dengan kegiatan manusia dalam bidang ekonomi. Industri dalam hal ini merupakan kegiatan manufaktur. Sementara industri kecil adalah kegiatan ekonomi atau unit usaha yang mempunyai pekerja sekitar lima sampai sembilan belas orang. Kemudian untuk industri rumah tangga adalah kegiatan ekonomi atau unit usaha yang mempunyai pekerja paling banyak empat orang, termasuk pengusahanya. Unit usaha tanpa pekerja juga masuk dalam kategori ini. Sementara industri menengah atau skala besar adalah unit usaha yang mempunyai pekerja lebih dari dua puluh orang (Tambunan 1999:112-113).

Secara historis, munculnya industri kecil sudah dimulai sejak sebelum kedatangan bangsa Eropa. Di pedesaan Jawa banyak terdapat kerajinan rakyat, yakni para penduduk yang membuat berbagai alat pertanian. Jenis industri ini sudah muncul lama dan dikembangkan penduduk di tingkat lokal. Industri rumahan ini juga menghasilkan barang kebutuhan seharihari untuk dijual sebagai tambahan penghasilan keluarga di pedesaan.
Selain itu, kerajinan rakyat yang cara produksinya didasarkan atas pesanan para pelanggan, seperti penjahit, tukang kayu, dan pandai besi juga mulai sudah muncul di daerah pedesaan. Industri kerajinan rakyat ini juga banyak muncul di awal abad ke-20 bersamaan dengan munculnya sektor manufaktur HindiaBelanda pada periode sebelumnya (Ridho'i 2019). Pada perkembangan selanjutnya muncul tempat-tempat kerja dengan para buruh yang dipimpin oleh pemilik perusahaan dengan mengandalkan pekerjaan tangan, seperti perusahaan keretek dan batik. Selanjutnya, muncullah pabrik-pabrik manufaktur yang menggunakan tenaga mesin maupun listrik (Siahaan 1996).

Pabrik keretek di Kediri termasuk dalam sentra industri kecil. Sistem kerjanya masih menggunakan tangan. Sementara buruhnya masih digaji mingguan atau harian. Secara historis, pabrik keretek di Kediri mempunyai keterkaitan dengan industri keretek Kudus beserta tokoh-tokoh Tionghoanya yang mengenalkan keretek di daerah ini sejak 1920-an (Arnez 2009; Margana et al. 2014; Tarmidi 1996). Belum ada data terkait pabrik keretek apa saja yang ada di Kediri tahun-tahun tersebut. Margana et al. (2014) hanya menjabarkan industri rokok yang hadir di daerah ini pada dua dekade setelahnya.

Fenomena industri skala mikro awal abad ke-20 ini memang menarik untuk diteliti. Pada saat itu, Depresi Ekonomi 1930 di Hindia Belanda menyebabkan ratusan ribu buruh 
perkebunan dan industri kolonial kehilangan pekerjaan. Akibatnya mereka kembali ke desa dan mengembangkan sektor ekonomi skala kecil berdasarkan keahlian masingmasing. Sejak saat itu di Indonesia mulai muncul sentra industri kecil, khususnya dalam rokok keretek. Ratusan industri keretek skala kecil tersebut muncul di daerah Kediri, Tulungagung, dan Kudus (Margana et al. 2014; Topatimasang 2010).

Hingga 1950-an masih tercatat ada dua industri keretek terkenal di Kediri. Pertama, yaitu pabrik rokok "N V Jiao San" yang didirikan Tjoa Kok Tjiang. Perusahaan ini berkembang pesat dan mengganti Namanya menjadi "NV 93". Kedua, yaitu pabrik rokok "Inghwie", yang juga milik orang Tionghoa. Di tahun 1956 salah seorang pegawai "NV 93”, Tjoa Ing Hwie, keluar dari pabrik rokok tersebut dan mendirikan pabrik keretek sendiri dengan merek "Inghwie". Pabrik inilah yang kemudian berubah nama menjadi “Gudang Garam" pada 26 Juni 1958 karena terinspirasi dari bangunan gudang garam yang berada di depan pabrik keretek "NV 93". Selain itu, Hwie juga mengganti namanya menjadi Surya Wonowidjoyo (Margana et al. 2014:119-120). Nama "Surya" kemudian dijadikan nama jenis produk rokok yang terkenal hingga saat ini, yaitu "Gudang Garam Surya."

Di daerah Kediri dan sekitarnya sejak periode tersebut juga berkembang pabrik rokok skala kecil. Pada pertengahan 1950-an di daerah ini masih tercatat ada empat puluh pabrik. Kemudian berkembang pesat hingga awal 1960-an menjadi kurang lebih sekitar 131 pabrik (Margana et al. 2014:120).

Fenomena kemunculan industri mikro di Kediri memang sesuai dengan kebijakan di Indonesia saat itu. Menurut Nugroho (2017), pada awalnya kebijakan industrialisasi yang digagas oleh Soemitro tahun 1950-an adalah industri skala kecil, menengah, dan besar. Kemudian, ketika Soemitro diangkat menjadi menteri perdagangan di era pemerintahan Orde Baru pada 1968-1973, ide atau gagasannya tentang industrialisasi memang benar-benar terwujud.

PDRB di daerah Kediri yang berjumlah sembilan sektor masih didominasi oleh industri pengolahan, termasuk pabrik keretek. Kesembilan sektor tersebut diantaranya adalah, pertambangan, pertanian, industri pengolahan, bidang konstruksi, perdagangan, listrik, air minum, restoran, perhotelan, sarana pengangkutan dan komunikasi, persewaan dan keuangan, serta sektor jasa (Rika 2012). Kontribusi utama untuk perekonomian di Kediri adalah sektor industri manufaktur (pengolahan). Selama Orde Baru sektor tersebut mengalami peningkatan dibandingkan sektor pertambangan dan penggalian kontribusinya yang mengalami penurunan. Pada kurun waktu tersebut, sektor perdagangan, restoran, dan perhotelan juga mengalami penurunan. Meski 
Handep Jurnal Sejarah dan Budaya Vol. 4, No. 1, Desember 2020, hlm. 1-18

demikian, dengan adanya industri keretek baik skala kecil, menengah, maupun besar perekonomian di Kediri masih tetap stabil. PDRB sebagai alat pengukur tingkat perekonomian penduduk menunjukkan kebergantungan di atas $70 \%$. Hal itu menandakan bahwa sektor ekonomi skala kecil harus mendukung PDRB agar kebergantungannya bisa turun. Salah satu pendukungnya yaitu pabrik keretek skala kecil.

Pada 1970-an, kretek masih menjadi primadona di kalangan penikmat rokok di Indonesia. Orangorang Indonesia lebih menyukai keretek dengan harga yang murah dibandingkan rokok putih yang harganya jauh lebih mahal. Seperti yang telah dibahas sebelumnya bahwa merokok keretek lebih dapat dinikmati dibandingkan rokok putih yang hanya digunakan sebagai penanda status. Pada periode ini potensi rokok keretek mampu menyaingi rokok putih impor karena promosinya yang juga mengikuti gaya asing (Arnez 2009). Oleh sebab itu, di Kediri mulai bermunculan pabrik keretek baru yang memanfaatkan momentum tersebut.

Beberapa contohnya yaitu di Kabupaten Kediri bagian selatan. Di sana ada bermacam-macam industri rumahan yang mampu menciptakan lapangan pekerjaan bagi penduduk dengan kemampuan ekonomi menengah ke bawah dan juga yang tingkat pendidikannya rendah, namun pabrik keretek lah yang mempunyai kontribusi paling signifikan saat itu.
Salah satu contoh industri rumahan yang berkembang pesat dan mulai membesar adalah pabrik keretek "Gudang Rasa". Pemiliknya adalah Estik. Pabrik keretek ini adalah usaha turun temurun keluarganya. Pada 1970an sempat berjaya karena pasar keretek saat itu sedang bagus, namun kemudian mandek pada 1990-an karena tingginya harga cengkih di pasaran. Meski demikian hingga saat ini pabrik keretek ini masih berproduksi. Pabrik ini mampu menghasilkan 22.000 sampai 28.000 batang rokok keretek per hari. Hasil dari produksi tersebut sebagian besar diperjualbelikan di daerah luar Kediri, bahkan hingga ke Bengkulu dan Kalimantan (Estik 2018).

Salah satu buruh pabrik keretek "Gudang Rasa" adalah Miam. Ia adalah buruh pabrik keretek dengan upah sekitar Rp15.000 per hari. Beliau menekuni pekerjaannya tersebut dengan spesialisasi sebagai buruh bathil. Bathil/mbathil adalah sebutan bagi buruh perempuan yang bekerja di dalam pabrik, yang tugasnya menggunting ujung rokok keretek yang sudah di-linting (gulung) dengan sistem kerja tangan (Margana et al. 2014:234). Sistem kerjanya borongan sesuai jumlah (kuantitas) rokok yang dihasilkan. Oleh pabrik, tiap 1.000 batang keretek, dihargai Rp12.000 yang dibagi berdua dengan buruh giling mitra kerjanya. Sebagai buruh bathil, perempuan separuh baya ini mendapat Rp5.000, sementara buruh giling mitranya memperoleh Rp7.000. Dalam sehari, mereka berdua mampu 
menghasilkan 3.000 batang keretek. Dengan demikian, upahnya tiap hari sekitar Rp15.000. Maka, pada setiap akhir pekan, Miam mengantongi sekitar Rp75.000, atau Rp300.000 per bulan, dari pekerjaan yang telah ditekuni selama 20 tahun terakhir (Miam 2018).

Pabrik keretek lainnya yang juga pernah berkembang pesat di tahun 1970-an yaitu Pabrik Keretek Kanigoro (yang lebih dikenal masyarakat dengan sebutan "KN"). Buruhnya mayoritas dari masyarakat sekitar lingkungan pabrik, yaitu Desa Kanigoro Kecamatan Keras, Kabupaten Kediri, yang notabene berpendidikan rendah (lulusan SD dan SMP). KN pernah menjadi pabrik keretek terkenal di tahun 1970-an. Dalam perkembangannya pabrik ini mengalami pasang surut yang diakibatkan oleh persaingan dagang dengan industri rokok besar, yaitu “Gudang Garam”. Selain itu, juga karena regulasi tentang tarif cukai rokok nasional yang semakin tinggi. Padahal pemerintah Kabupaten Kediri sangat mendukung produksi dan eksistensi pabrik keretek rumahan tersebut. KN sempat berhenti berproduksi selama dua tahun pada periode 1990-an karena peminat rokok keretek yang beralih ke rokok filter. Setelah itu, hingga saat ini KN kembali berproduksi rokok keretek yang dipasarkan di daerah sekitar Kabupaten Kediri (Mawardi 2018).

Sejak 1970-an pabrik keretek memperlihatkan perkembangan yang cukup bagus, namun juga sempat mengalami kemunduran karena swasembada cengkih dan kebijakan monopoli Badan Penyangga dan Pemasaran Cengkeh (BPPC) di awal 1990-an (Margana et al. 2014:149). Kebijakan tersebut mengharuskan perusahaan rokok untuk membeli cengkih ke BPPC dengan harga yang ditentukan. Keberatan mulai muncul dari beberapa pabrik keretek di Kediri karena seringkali harga cengkih yang dibeli dari BPPC lebih mahal dibandingkan dari petaninya langsung (Arnez, 2009:57; Margana et al. 2014).

Undang-undang No. 11 Tahun 1995 yang mengatur tentang cukai juga terkesan memberatkan pengusaha keretek skala mikro. Denda Rp100.000.000 bagi pabrik keretek yang tidak melaporkan usahanya dan tidak memiliki dokumen resmi dari pemerintah membuat kondisi pabrik kretek di Kediri semakin terpuruk (Undang-Undang Republik Indonesia No. 11 Tahun 1995 tentang Cukai, 1995). Penulis sependapat dengan pernyataan Tarmidi (1996) yang di akhir tulisannya menyimpulkan bahwa intervensi pemerintah melalui kebijakan mekanisasi, pajak/cukai, dan investasi asing menyebabkan banyak pabrik rokok skala mikro akhirnya bangkrut.

Tidak hanya itu, bahkan pada perkembangan selanjutnya rokok (keretek maupun rokok putih) juga banyak dipersoalkan karena urusan kesehatan. Beberapa organisasi sosial dan keagamaan di Indonesia yang mengritik tajam yaitu Gerakan Anti Tembakau dan Rokok Indonesia 
(GATRI), Yayasan Lembaga Konsumen Indonesia (YLKI), Komisi Nasional Perlindungan Anak, dan Pengurus Pusat Muhammadiyah (Nawiyanto 2013:113).

Seiring perkembangan zaman, industri rokok keretek mempengaruhi sosial-ekonomi masyarakat Kediri oleh karena keretek sudah dianggap sebagai ciri khas masyarakat Kediri dan industri rumahan rokok keretek berkembang pesat hingga menjadikan Kediri sebagai pusat industri keretek terbesar pertama di Jawa Timur (Hartati 2018).

\section{SIMPULAN}

Berdasarkan uraian di atas dapat disimpulkan bahwasannya kebiasaan ngudud di daerah Kediri merupakan pengaruh dari pengenalan tembakau oleh orang-orang Tionghoa sejak 1920an. Sejak dikenalnya penanaman tembakau di Jawa, khususnya Kediri, masyarakat sekitar mulai terbiasa dengan kebiasaan ngudud keretek. Hal itu tidak bisa hilang hingga saat ini, karena setiap ada acara maupun dalam kehidupan sehari-hari di daerah ini masih menggunakan rokok keretek sebagai hidangan wajib.

Industri kecil rokok keretek mempunyai keterkaitan dengan kebiasaan ngudud. Oleh karena keretek sudah menjadi candu, Kediri sudah mengembangkan perkebunan cengkih dan tembakau yang nantinya digunakan sebagai bahan baku rokok keretek. Ketersediaan bahan baku dan munculnya pabrik keretek membuat masyarakat kediri tidak bisa menghentikan kebiasaan ngudud-nya. Ditambah lagi keretek sudah menjadi menjadi pendamping utama bagi kehidupan sehari-hari untuk urusan sosial maupun keagamaan. Jadi keretek dan $n g u d u d$ hingga saat ini masih tetap hidup dalam keseharian masyarakat kediri.

Tema menarik untuk penelitian selanjutnya yaitu tentang sejak kapan dan bagaimana Kediri memproduksi bahan baku keretek, kemudian seperti apa perkembangan industri keretek skala mikro di Kediri pada periode kolonial (1920-1940). Penelitian lebih lanjut sangat dianjurkan untuk melengkapi kekurangan dari penelitian ini.

\section{DAFTAR SUMBER}

Arnez, Monika. 2009. "Tobacco and Kretek: Indonesian drugs in historical change." ASEAS Austrian Journal of South-East Asian Studies, 2(1), 49-69.

Basuki, Irawan Santoso Suryo. 2010. "Kelompok Budaya Para Perokok." Diakses pada 11 Januari 2020, (http://scola-irawan.blogspot.com/ 2010/05/kelompok-budaya-paraperokok-rokok.html).

Budiman, Amen dan Onghokham. 1987. Rokok Kretek: Lintasan Sejarah dan Artinya bagi Pembangunan Bangsa dan Negara. Kudus: Djarum Kudus. . 2016. Hikayat Kretek. Jakarta: Gramedia. 
DM, Abhisam, Hasriadi Ary, dan Miranda Harlan. 2012. Membunuh Indonesia: Konspirasi Global Penghancuran Kretek. Jakarta: Kata-kata.

EA, Puthut, et al. 2013. Ekspedisi Cengkeh. Makassar: Inninawa \& Layar Nusa.

Lubis, Mochtar. 1963. Twilight in Jakarta. $2^{\text {nd }}$ ed. London: Hutchinson \& Co.

Margana, Sri. et al. 2014. Kretek Indonesia: Dari Nasionalisme hingga Warisan Budaya. Yogyakarta: Jurusan Sejarah FIB UGM dan Puskindo.

Masyhari, Nanang. 2019. "Pertumbuhan Ekonomi di Kota Kediri Tanpa Industri Tembakau Capai 7,02\%." Diakses 3 Desember 2019 (https:// beritajatim.com/politikpemerintahan/pertumbuhanekonomi-di-kota-kediri-tanpaindustri-tembakau-capai-702/).

Nawiyanto. 2013. "Debating 'Golden Leaf': A Historical Perspective on Socio-Cultural Aspects of Smoking and Tobacco Control." LITERASI: Indonesian Journal of Humanities, 3(2): 109-117.

Nugroho, Wahyu Budi. 2017. "Konstelasi Ekonomi, sosial dan Politik di Era Orde Baru (Seminar Peringatan "19 Tahun Reformasi")." Diakses pada 3 Desember 2019. (https:// simdos.unud.ac.id/uploads/

file_penelitian___ dir/ f4641786b89cc4194a2409236d7el1f5.pdf).

Peringatan Panca Warsa 1977-1982 DPRD Tingkat II. 1983. Kediri: Pemerintah Kabupaten Kediri.

Purbasari, Imaniar. 2010. Perkembangan Industri Rokok Kretek Kudus 1908-1964. Semarang: Universitas Negeri Semarang. Diakses pada 3 November 2019. (https:// digilib.uns.ac.id/dokumen/detail/ 12829/Perkembangan-industrirokok-kretek-Kudus-1908-1964).

Ridho'i, Ronal. 2019. “Antara Pemerataan dan Eksploitasi Lahan: Sidoarjo dalam SWP Gerbangkertosusila, 1996-2011". Handep: Jurnal Sejarah dan Budaya. Vol. 2, No. 1, Desember 2018: 1-16.

Rika, Rita. 2012. "Analisis sektorsektor ekonomi dalam rangka pengembangan kebijakan pembangunan Ekonomi Kota Kediri." Tesis, Universitas Negeri Malang, Malang.

Siahaan, Bisuk. 1996. Industrialisasi di Indonesia Sejak Hutang Kehormatan Sampai Banting Stir. Jakarta: Pustaka Data.

Sukirno, Sadono. 2010. Makroekonomi: Teori Pengantar. Jakarta: Raja Grafindo Persada.

Tambunan, Tulus. 1999. Perkembangan Industri Skala 
Kecil di Indonesia. Jakarta:

Salemba Empat.

Tarmidi, Lepi. T. 1996. “Changing structure and competition in the kretek cigarette industry." Bulletin of Indonesian Economic Studies, 32(3):85-107.

Topatimasang, Roem. 2010. Kretek: Kajian Ekonomi dan Budaya 4 Kota. Yogyakarta: Indonesia Berdikari.

Undang-Undang Republik Indonesia No. 11 Tahun 1995 tentang Cukai. 1995. Diakses pada 17 Maret 2020 (https://pih.kemlu.go.id/files/UU_ Cukai 11 Tahun 1995.pdf).

Wawancara Estik. Kediri, 9 November 2018.

Wawancara Hartati. Kediri, 3 November 2018.

Wawancara Mawardi. Kediri, 3 November 2018.

Wawancara M. Miam. Kediri, 12 Desember 2018.

Wibisono, Nuran. 2013. Dunia Iskandar: Tembakau, Humanisme, Kepemimpinan. Jakarta: Indonesia Berdikari. . 2014. Kretek: Kemandirian dan Kedaulatan Bangsa Indonesia. Jakarta: KNPK Press. 